\title{
The Impact of Service Learning in the Development of Student Teachers' Socio-Educational Commitment
}

\author{
Juan Tomás Asenjo (D), Elsa Santaolalla *(D) and Belén Urosa (D) \\ Department of Education, Research Methods and Assessment, Faculty of Humanities and Social Sciences, \\ Comillas Pontifical University, 28049 Madrid, Spain; jtasenjo@comillas.edu (J.T.A.); burosa@comillas.edu (B.U.) \\ * Correspondence: esantaolalla@comillas.edu
}

Citation: Asenjo, J.T.; Santaolalla, E.; Urosa, B. The Impact of Service Learning in the Development of Student Teachers' Socio-Educational Commitment. Sustainability 2021, 13, 11445. https://doi.org/10.3390/ su132011445

Academic Editors: Maki Ikegami and Iain Patton

Received: 10 September 2021

Accepted: 14 October 2021

Published: 16 October 2021

Publisher's Note: MDPI stays neutral with regard to jurisdictional claims in published maps and institutional affiliations.

Copyright: (c) 2021 by the authors. Licensee MDPI, Basel, Switzerland. This article is an open access article distributed under the terms and conditions of the Creative Commons Attribution (CC BY) license (https:// creativecommons.org/licenses/by/ $4.0 /)$.

\begin{abstract}
This research arises from the university's need to contribute to the training of professionals, especially teachers, who, in turn are committed to contribute to a more sustainable and socially just world at the institutions for which they are professionals. In this context, a pedagogical approach emerges to promote the development of the civic and social competences of higher education students' using the methodology of Service Learning. The aim of this study is to analyse the acquisition and development of the socio-educational commitment and self-efficacy variables of student teachers based on their participation in Service Learning programmes, comparing this with the results of carrying out university volunteering activities. A quantitative correlational study was carried out with preservice teachers $(\mathrm{N}=207)$. The basic hypothesis is that the results would be in favour of the participation in Service Learning activities on the fundamental variables of the study: socioeducational commitment, teaching self-efficacy and self-efficacy in the creation of instructional materials. For this purpose, a specific scale was designed to measure Teachers' socio-educational commitment with favourable psychometric characteristics. The results show sufficient empirical evidence $(p<0.01)$ for the development of socio-educational commitment and self-efficacy variables in favour of those who participated in Service Learning programmes.
\end{abstract}

Keywords: social responsibility; sustainable university; teacher education; social and emotional learning; psychosocial development; volunteering; teaching self-efficacy; social justice; quality education; education for sustainable development

\section{Introduction}

A worldwide, complex, and interrelated society, due to the phenomenon of globalisation, manifests new forms of learning to which the traditional instructional culture would appear to have difficulties adapting to. Additionally, the COVID-19 pandemic and the serious healthcare, social and human consequences it has caused around the world have impacted the educational field, accentuated by the requirement to transform teaching and learning models in a sudden and extreme manner [1-3], generating a high level of uncertainties [4]. In the midst of this rapid change, there seems to be a consensus that society can count on is a firm educational response [5], which involves working collaboratively in terms of ecology and sustainability [6].

The importance of the events that we are experiencing has led us towards the adaptation of an educational paradigm that coexists amid constant transformations, where the university, beyond managing the knowledge society, is challenged to face a series of urgent tasks, among which are task crucial to ensure a critical education and to strengthen social commitment [7]. This situation has forced us to work on the idea of a new classroom concept, the renewal of which goes beyond the replacement of some teaching methods with others. This model revolves around an essential educational task that is none other than ensuring that students establish real links between the knowledge acquired and the potential situations that they will have to deal with professionally, socially, and personally. Educational institutions face the need to make a proposition that goes beyond the 
curricular area to become involved in civic and moral objectives across the board, in line with the ability to adapt and to develop skills, making students social agents of change based on an education of solidarity and ethics. This would be a matter of overcoming the individual-society dichotomy and facing global challenges through an active and committed citizenship. This is where the leading role of higher education institutions today acquires a remarkable importance; for the ability to establish relationships between what is proposed in the classroom and what occurs in society [8]. This arises from the need to establish a real connection among academic approaches and to promote a social commitment among students [9].

The need for a new figure of the citizen emerging from the universities is defined by a philanthropic profile based on personal responsibilities [10]. For this university-based figure to emerge, learning has to balance the academic with the practical. However, if there is one idea that is repeated it is that of social justice, constantly present in the academic literature [11-14], even more so in times of the COVID-19 pandemic [15].

In this context, the socio-educational commitment construct acquires prominence by locating in university centres the need to develop spaces for reflection and social action [16] and to specify the evidence that speaks to a conversation between theory and practice in real contexts [17], giving rise to a teacher competencies profile characterised by promotion and socio-educational actions. This construct acquires its relevance in the research that we are presenting because the aim of the study is to analyse the acquisition and development of the socio-educational commitment of student teachers. The commitment in which the social and educational aspects are combined with the motivational aspects, is defined in our study in terms of Awareness of social justice, for the range of attitudes, and as a Socio-educational action for the field of performance. These two dimensions are deeply intertwined.

The university is one of the institutional referents that society has, both from the perspective of educating and training qualified professionals and because it represents the vanguard in the promotion of knowledge. Teachers, in turn, have acquired a new position added to their role. In conjunction with teaching, research, and management, they perceive that society demands a teaching profile that leads and promotes pro-social attitudes.

There are various methodologies that are compatible with the purpose of merging the academic and the social. Service Learning is one of them [18], as is the inclusion in undergraduate degrees of the subject, Education for Peace and Equality [19], Education for Peace and Good Relations [20], education centred in Human Development [21], or acknowledging the role of the university tutor as an agent of change [22]. Even so, Service Learning enjoys a prominent position on campus as it has become part of the field of educational innovation [23], possessing a structure that is included in universities' new management policies, in the strategy known as University Social Responsibility, currently referred to as the concept, "sustainable university".

A sustainable university is committed to its current actions as an institution, but also to the training of professionals who in turn are committed to contributing to a more sustainable and socially just world at the institutions with which they are professionally associated. This is a change that Sirignano [24] synthesises in the transition from two dimensions: research and education, to three dimensions, in which direct participation in the progress of society is present. A way in which the university can respond to the questions posed by the environment [25] and meet the requirements set out in the European Higher Education Area, in which the promotion of social responsibility aligns with the aim of contributing to the development of qualified and supportive citizens, is in the civic learnings that are translated into community attitudes [26]. That is, to explore in greater depth the discourse of co-responsibility between the university environment and social structures to build a civic culture, promote an awareness of the most vulnerable realities that become visible in an interconnected society, and build links with the needs of disadvantaged environments. 
It is in this context that the Service Learning approach emerges, formulating a methodology committed to establishing synergies between the academic content and the students' civic commitment [9]. The difficulty of implementing civic projects in academic programmes has found an answer in the field of innovation, establishing the relevance of the construction of civic and social competencies [27] that structure the skills and attitudes of an ethical, committed academic community with a global citizenship.

One of the challenges present at the outset of Service Learning has been to present a project different from the volunteering actions that, intermittently and occasionally, have accompanied academic routines. From an approach inspired by mainstreaming and curricular requirements, it has sought its space by integrating itself into the management policies of the ethical quality entailed within the field of University Social Responsibility. Within the framework of this renewed civic commitment of university centres, Service Learning acquires a differentiated profile with respect to volunteering by adding different methodological and evidentiary characteristics $[18,28]$; stressing the evaluation of learning processes [29]; facilitating, together with experience, theorising and research [30]; connecting with mobility and digital technologies [31]; developing emotional competencies [32]; and promoting civic literacy [33] that imbues students and graduates with the necessary attitudes of responsibility and solidarity towards a society that is certainly in need of them.

The research we are presenting, based on Teacher Education in Spain, aims to address the previously stated problem with the purpose of analysing the acquisition and development of the socio-educational commitment of preservice teachers based on participation in Service Learning programmes, while comparing it with the results of university volunteering proposals. Therefore, the main variable of the study is the socio-educational commitment.

Additionally, two secondary variables, both related to self-efficacy, have been taken into account: teaching self-efficacy and self-efficacy in the creation of instructional materials. Self-efficacy, understood as a relationship between expectations of personal effectiveness and coping behaviours [34], has gained prominence in the definition of professional teacher profiles, specifically in the search for leadership in educational communities [35] and in its link with emotional competencies [36]; significant relationships have also been established between collaborative work and self-efficacy [37] and between the proactive personality and self-efficacy [38]. The evidence that shows that teacher self-efficacy is comparable to knowledge and skills in teaching and learning processes $[39,40]$ and the relevance of associating social participation and commitment to the community with self-efficacy [41] motivated us to assess the levels of self-efficacy present in Teacher Education and its effect on a potential social, citizen and civic self-efficacy in future graduates.

Another particularity of our work materialised when assessing the effect of Service Learning on teaching self-efficacy, with the assumption that preservice teachers have regarding their performance, and whether this attitude is consolidated in a self-efficacy that trains the student teacher to create instructional materials. This is because of the relevant role that educational resources have in the learning process and because the majority of the Service Learning programmes, and Volunteering activities were related with the selection and design of instructional materials.

According to the literature, the performance of social activities has an impact on the development of better attitudes of service to society. However, the type of activities that are best for promoting these attitudes have not been studied in depth. We believe that not all activities have the same impact and that those that are carried out in the university environment as part of the students' training plans will be more effective for this purpose. That is to say, those activities that are carried out when taking into account the activities of the students' professional profiles bring the subjects closer to a quasi-professional practice. For this reason, the fundamental hypothesis of our study is that service-learning activities contribute more than volunteering activities to the development of civic and social competences in student teachers, specifically socio-educational commitment, and the strengthening of their entity as professionals, especially in their self-efficacy as teachers. 
In conclusion, the aim of the study is to compare the different effectiveness of volunteering versus Service Learning activities on the development of socio-educational commitment, teaching self-efficacy and self-efficacy in the creation of the instructional materials of the preservice teachers.

\section{Materials and Methods}

A quantitative correlational study was carried out with the application of a questionnaire and three specially designed Likert scales to measure the main variables of the study. The study was conducted in a natural research situation, with education students at a Spanish university.

The instruments were administered to all the students in Teacher Education, the response was anonymous and voluntary. In the questionnaire, they were asked about some socio-demographic variables and about their participation in volunteering and/or Service Learning activities. Subjects who had not participated in any of these activities were excluded from the study. It was, therefore, a non-probabilistic convenience sample.

Depending on the subject matter, studies in the social field tend to have some difficulties in using experimental methodologies. Analysing activities that are voluntary in nature, in which the subjects choose whether to participate, limits the possibility of creating groups where the subjects are randomly assigned to the different experimental conditions. This is the difficulty we encountered when carrying out the research. On the one hand, as far as volunteering activities are concerned, students tend to carry them out in social organisations other than the university itself and it is usual for them to be carried out in parallel with their studies. On the other hand, Service Learning activities are usually incorporated into the training activities of some subjects in their syllabi or are carried out through the university's own services outside their degree and, in some cases, are of a voluntary nature. This may incorporate certain biases in our study as we have not been able to control for extraneous variables such as time availability, attitude towards carrying out services to society and other similar variables, which affect the results and the extrapolation capacity of this research.

Therefore, the choice of methodology was largely conditioned to the specific situation in which the research was carried out and the voluntary nature of the activities compared. It would be highly desirable to be able to develop future studies with experimental methodological approaches that would make it possible to reduce these limitations.

As a correlational study, the research design involved a single data collection of all the research variables from all the subjects who took part in the study. Based on their responses, subjects were classified according to their participation in Service Learning activities, volunteering, or both. Their responses were compared with each of the main research variables.

\subsection{Participants}

In this research, which was carried out during the 2018-2019 academic year, 207 preservice teachers at the Comillas Pontifical University participated. These students were mostly women $194(93.7 \%)$, while $13(6.3 \%)$ subjects in this group were men. The mean age of the group was 20.56 years $(\mathrm{SD}=1.4)$.

In terms of degrees, 119 students $(57.5 \%)$ were studying for a Primary Education degree and 88 (42.5\%) for a degree in Early Childhood Education.

The distribution in terms of the years of the course was balanced: 51 students $(24.6 \%)$ were in 2 nd year, $58(28 \%)$ in 3rd year, $50(24.2 \%)$ in 4 th year and $48(23.2 \%)$ in 5 th year. Firstyear students were excluded from the study as they had not yet completed any university Service Learning projects. It was therefore a non-probabilistic convenience sample.

\subsection{Variables and Instruments}

A questionnaire was provided to all the students involved, which collected a set of sociodemographic variables with two questions referring to whether they had participated 
in volunteer and Service Learning activities. This instrument also collected information on the three variables of the study that were measured through six-point Likert scales ranging from 1 (very little/barely capable) to 6 (a lot/very capable).

For the main variable of the study, an ad hoc scale was designed to measure socioeducational commitment of the preservice teachers.

Socio-educational commitment, as defined above, is the attitude of teachers that leads to their sensibilization to social justice issues, especially educational issues, and causes them to carry out educational activities in social environments.

To create this scale, a process of operationalisation of the variable was carried out considering two main dimensions: the awareness of social justice in educational environments, and socio-educational action, which corresponded to the behaviour of socio-educational commitment carried out by trainee teachers in their professional practice.

A set of 16 items was designed, 8 for each of the two dimensions. A basic validation process was conducted after the scale was applied.

In order to validate the scale, analyses were carried out to check the discriminatory capacity of each item and its association with the rest of the items of the scale through Pearson correlations and an analysis of the change in the internal consistency of the scale without the item (Cronbach's alpha). In addition, the saturation indices of each item in the factors extracted from the scale were checked in a first exploratory factor analysis carried out with the scale. With this information, the included items decreased the alpha of the entire scale and at the same time their saturation index did not clearly associate them with one of the factors which was eliminated.

From the evaluation of the statistical results, it was decided to eliminate 3 items that referred to the first dimension, leaving a definitive instrument (Table 1) with 13 items: 5 of the dimension Awareness of social justice and 8 of the dimension, Socio-educational action.

Table 1. Items of the scale to assess the socio-educational commitment of preservice teachers.

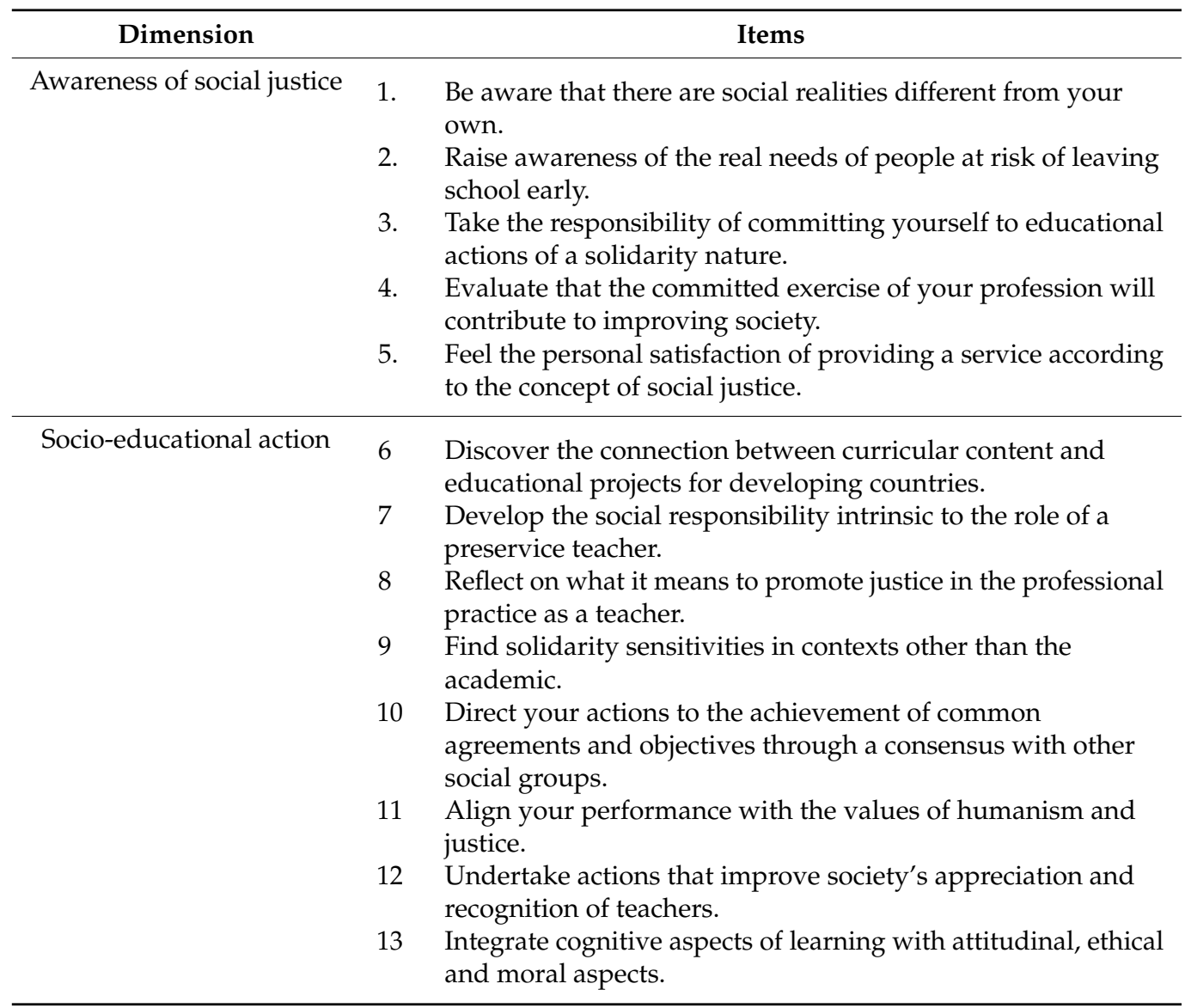


With the final version of the scale, an exploratory factor analysis of principal components and Varimax rotation were carried out. The adjustment data were appropriate: the Kaise-Meyer-Olkin measurement had a value of 0.935 and the Bartlett sphericity was significant. The analysis concluded that two factors coincided in their content with the dimensions raised in the operationalisation process. In Table 2 one can analyse the rotated components matrix, where Factor 1 refers to the socio-educational action dimension and factor 2 refers to the awareness of social justice dimension. The total explained variance was $64.42 \%$ (36.34\% for the first factor and $28.08 \%$ for the second factor), which indicated an appropriate explanatory power of the factorial structure.

Table 2. Matrix of rotated components from the socio-educational commitment scale.

\begin{tabular}{ccc}
\hline Item No. & Factor $\mathbf{1}$ & Factor 2 \\
\hline 12 & 0.788 & \\
11 & 0.788 & \\
10 & 0.780 & \\
8 & 0.771 & \\
13 & 0.769 & \\
7 & 0.715 & \\
9 & 0.638 & \\
6 & 0.467 & \\
1 & & 0.851 \\
2 & & 0.798 \\
3 & & 0.729 \\
4 & & 0.655 \\
5 & & 0.646 \\
\hline
\end{tabular}

In addition, the internal consistency of this instrument was analysed. A Cronbach alpha of $\alpha=0.931$ resulted from the global scale. The internal consistency of the subscales that corresponded to the two dimensions of the instrument was worth noticing, $\alpha=0.866$ for the sub-scale of awareness of social justice and $\alpha=0.911$ for the sub-scale of socio-educational action. Therefore, both, the content structure of the general scale and its capacity of discrimination were appropriate. These data confirm the structure of the dimensions of the analysed construct.

The secondary research variables are general teacher self-efficacy, as well as selfefficacy for the selection and design of instructional materials.

General teacher self-efficacy can be defined as teachers' own perceptions of their abilities to perform their roles as teachers adequately. In other words, teachers' confidence in their own ability to help students to learn. This perception includes their ability to organise teaching processes, set objectives and competences, schedule learning activities and evaluate the results achieved by their students, as well as their communication, motivation, and classroom management skills.

A reduced scale of the one proposed by Prieto [39] was used to measure this variable.

The original scale was composed of 44 items, with a factor structure of 4 dimensions: (1) Planning of teaching, (2) Involvement of students in learning, (3) Interaction and creation of a positive climate and (4) Assessment of learning and teacher self-assessment. The authors note that, in the validation of the scale, a Cronbach's alpha of 0.947 was obtained. The reduced 12-item scale (Table 3) applied in this research had a factorial structure of 2 factors: (1) Involvement and interaction with learners and (2) Teaching planning. This reduced scale had an internal consistency of $\alpha=0.885$ in the sample of this study. 
Table 3. Items of the reduced 12-item scale to assess general teacher self-efficacy.

\begin{tabular}{|c|c|}
\hline Dimension & Items (Indicate the Extent to Which You Feel Capable to...) \\
\hline $\begin{array}{l}\text { Involvement and interaction } \\
\text { with learners }\end{array}$ & $\begin{array}{l}\text { 1. Give students an active role in class, more as builders of } \\
\text { 2. Adapt, when planning lessons, to the needs of the } \\
\text { students (motivation, interests, and knowledge, etc.). } \\
\text { 3. Encourage positive attitudes towards the lessons. } \\
\text { 4. Introduce changes in lessons if this is required by the } \\
\text { process the students follow while learning. } \\
\text { 6. Encourage student participation in class. } \\
\text { 6. Make students understand the meaning and usefulness } \\
\text { 7. Be flexible in your teaching even if you have to change } \\
\text { 8. Actively involve students in the learning activities that } \\
\text { you propose in class. }\end{array}$ \\
\hline Teaching planning & $\begin{array}{ll}9 & \text { Spend enough time planning lessons. } \\
10 & \text { Prepare the material you are going to use in class. } \\
11 & \begin{array}{l}\text { Review your teaching practices to identify areas for } \\
\text { improvement. }\end{array} \\
12 & \text { Design the structure and content of each lesson. }\end{array}$ \\
\hline
\end{tabular}

The other secondary variable in the study was self-efficacy in the selection and design of instructional materials. We can consider this variable as the confidence that the subjects have when being able to select, adapt or design instructional materials that consider the specific needs of the learners. For its evaluation, the authors used a set of 5 items (Table 4) that they formulated for this purpose. This scale had a remarkable reliability with a Cronbach alpha of $\alpha=0.902$.

Table 4. Items of the scale to assess self-efficacy in the selection and design of instructional materials.

Items (Indicate the Extent to Which You Feel Capable to...)

1. Select the most appropriate material resources for each student group.

2. Identify which didactic resources would be necessary to carry out teaching/learning activities in specific educational settings.

3. Adapt existing teaching materials to the specific needs of an educational community.

4. Design and develop specific instructional materials taking into account the needs of the learners.

5. Design and develop teaching materials with limited resources according to the educational context in which the school is located.

The data collection process was carried out in the second quarter of the 2018-2019 academic year through online questionnaires whose link was provided to the students by email through the tutors so that the students could fill them out autonomously.

\section{Results}

Of the total of 207 students, $77.8 \%$ (161) participated in some volunteering activity and $58 \%$ (120) in a Service Learning project. Ninety-one of these students (44\% of the total) carried out the Service Learning project as part of one of the modules in their curriculum; most of them $(70.73 \%)$ in relation to some of the subjects in their curriculum and the rest $(29.16 \%)$ through activities carried out by other services of the university.

These data show the high participation of students in education undergraduate degree courses in both volunteering activities and Service Learning activities.

In order to be able to complete an adequate analysis of the data collected (Table S1: Study data collection) with the different scales, the overall scores of the sample in each 
of the variables of the study were calculated. A general descriptive study was conducted with the mean $(\mathrm{M})$ and standard deviation (SD).

In Table 5, we can see that all the scores are very high in all the variables of the study with respect to the different scales; in all cases, the results are very high and homogeneous. The minimum and maximum values of each scale are shown in brackets.

Table 5. Descriptive statistics of the variables of the study.

\begin{tabular}{cccc}
\hline Variable & Dimensions & M & SD \\
\hline \multirow{3}{*}{ Socio-educational commitment } & Awareness of social justice (5-30) & 25.77 & 4.09 \\
& Socio-educational action (8-48) & 38.03 & 6.49 \\
\cline { 2 - 4 } & Total (13-78) & 63.80 & 9.86 \\
\hline \multirow{2}{*}{ Secondary variables } & Teaching self-efficacy (12-72) & 57.54 & 7.32 \\
& Self-efficacy with materials (5-30) & 22.95 & 4.05 \\
\hline Note: $\mathrm{N}=$ 207 students. & & &
\end{tabular}

As indicated above, the aim of the study is to ascertain the main effect of carrying out Service Learning and Volunteering programmes and the effect of their interaction on the main variable of the study, which is socio-educational commitment, and the secondary variables, namely General teaching self-efficacy and Self-efficacy in creating materials.

In order to analyse the impact of the volunteering and Service Learning activities on the main variables of the study, a two-factor Analysis of Variance (ANOVA) was implemented for each of the variables to ascertain the main effect of carrying out Service Learning and Volunteering activities and the interaction effect between these two factors. The data analysis program SPSS version 26 was used.

Table 6 shows that the main effect of carrying out Service Learning programmes was statistically significant in terms of socio-educational commitment $(p<0.01)$, and in the dimension of socio-educational action $(p<0.05)$ of this variable, in favour of those who participated in this activity. However, the analysis in assessing the effect of volunteer activities was not significant in any of the dimensions of socio-educational commitment. Moreover, neither was the empirical evidence found on the existence of interaction between the joint performance of Service Learning activities and volunteering work, nor in the awareness of social justice, nor in socio-educational action.

Table 6. Results of the ANOVA for the main variable.

\begin{tabular}{ccccccc}
\hline \multirow{2}{*}{ Variable/Dimension } & \multicolumn{2}{c}{$\begin{array}{c}\text { Factor 1: } \\
\text { Service Learning }\end{array}$} & \multicolumn{2}{c}{$\begin{array}{c}\text { Factor 2: } \\
\text { Volunteering }\end{array}$} & Interaction \\
\cline { 2 - 7 } & F & Partial Eta2 & F & Partial Eta2 & F & Partial Eta2 \\
\hline Socio-educational commitment & $9.428^{* *}$ & 0.044 & 0.162 & 0.001 & 0.007 & 0.001 \\
Awareness of Social Justice & 2.528 & 0.012 & 1.164 & 0.006 & 1.529 & 0.007 \\
Socio-educational Action & $6.815^{*}$ & 0.032 & 2.448 & 0.012 & 0.127 & 0.001 \\
\hline
\end{tabular}

Note: ${ }^{*} p<0.05 ; * * 0.01$

Similarly, a two-factor Analysis of Variance (ANOVA) was performed for each of the secondary variables of the study. The results are displayed in Table 7.

Table 7. Results of the ANOVA for the secondary variables.

\begin{tabular}{ccccccc}
\hline \multirow{2}{*}{ Variable/Dimension } & \multicolumn{2}{c}{$\begin{array}{c}\text { Factor 1: } \\
\text { Service Learning }\end{array}$} & \multicolumn{2}{c}{$\begin{array}{c}\text { Factor 2: } \\
\text { Volunteering }\end{array}$} & \multicolumn{2}{c}{ Interaction } \\
\cline { 2 - 7 } & F & Partial Eta2 & F & Partial Eta2 & F & Partial Eta2 \\
\cline { 2 - 7 } & $14.204^{* * *}$ & 0.065 & 0.071 & 0.001 & 2.354 & 0.011 \\
Self-efficacy with materials & $11.608^{* *}$ & 0.054 & 0.316 & 0.002 & 1.817 & 0.009 \\
\hline
\end{tabular}


Table 7 shows that the main effect of the performance of Service Learning programmes was statistically significant in the two secondary variables of the study: general teaching self-efficacy and self-efficacy in the production of materials $(p<0.001$ and $p<0.01$, respectively), in both cases in favour of the subjects who performed this activity. However, the main effect of volunteering work was not significant in either of the two secondary variables of the study. Neither was empirical evidence found on the existence of an interaction between the joint performance of Service Learning activities and volunteering, nor in the general teaching of self-efficacy, nor in the self-efficacy of the design of the materials.

To verify the relationship between the different variables of the study, a study of the correlations was carried out through Pearson's r-coefficient. Table 8 shows the results and it is clear that, in all cases, the correlation was statistically significant $(p<0.01)$ among all variables.

Table 8. Correlations between the different variables of the study.

\begin{tabular}{ccccc}
\hline & $\begin{array}{c}\text { Awareness of Social } \\
\text { Justice }\end{array}$ & $\begin{array}{c}\text { Socio-Educational } \\
\text { Action }\end{array}$ & $\begin{array}{c}\text { Teaching } \\
\text { Self-Efficacy }\end{array}$ & $\begin{array}{c}\text { Self-Efficacy with } \\
\text { Materials }\end{array}$ \\
\hline Socio-educational action & $0.724^{* *}$ & & & \\
Teaching self-efficacy & $0.417^{* *}$ & $0.439^{* *}$ & $0.785^{* *}$ & $0.462^{* *}$ \\
Self-efficacy with materials & $0.381^{* *}$ & $0.958^{* *}$ & $0.456^{* *}$ \\
Socio-educational commitment & $0.891^{* *}$ & & 0.401 \\
\hline
\end{tabular}

Note: $\mathrm{N}=207 ;{ }^{* *} p<0.01$.

\section{Discussion}

This research arises from the necessity for the university to contribute to the training of professionals, specifically teachers, who in turn are committed to contributing to a more sustainable and socially just world at the institutions they are professionally associated with.

As previously mentioned, the aim of this study is to analyse the impact of Service Learning programmes on the development of civic, social and professional competences in student teachers and their possible differentiation with respect to participation in volunteering activities. After carrying out this research, the results show sufficient empirical evidence $(p<0.01)$ for the development of socio-educational commitment and self-efficacy variables in favour of those who participated in Service Learning programmes. Therefore, we can conclude that participation in teacher education Service-Learning programmes is shown to be more relevant than participation in volunteering projects in the development of the global socio-educational commitment, as well as in the strengthening of teaching self-efficacy and self-efficacy in the selection and design of instructional materials. Consequently, the fundamental hypothesis of our study has been verified.

With regard to the difference between Service Learning and the Volunteering variable, from the analysed data, we conclude that what is truly effective is to participate and perform Service Learning; participating in a Service Learning programme is the best way to develop the socio-educational commitment of teachers, and demonstrates that the effect of Service Learning activities is not the same as that of volunteering.

Service Learning has generated extensive educational research with a growing scientific production [42], in which international organisations have carried out parallel assessments of civic participation and Service Learning activities [43]. Service Learning represents the opportunity to validate learning, to establish the relationship between experiential activities and learning outcomes [44], the latter being one of the main reasons for its growth.

The conclusion of our study underlines the importance and value of Service Learning in many different aspects already acknowledged by numerous researchers. On the one hand, the results are consistent with those from other studies, according to which the pedagogical practices of Service Learning correlate with a change or the promotion of pro-social attitudes both among teachers [45] and students [46]. On the other hand, the 
results emphasise that those students who participate in Service Learning projects develop a commitment to their environment from a transformative perspective in a special way [11], encouraging students to develop critical thinking skills and multicultural awareness [47], acquire intercultural skills, learn to recognise and mediate in their community [48], and prepare future teachers to face injustice and work toward socially supportive actions [12].

Additionally, this research extends the study of the relation between the Service Learning methodology and pro-social and social justice attitudes by introducing the dimension of volunteering, which represents a differential contribution with respect to previous studies. The academic literature on this topic lacks the simultaneous analysis of both Service Learning and Volunteering on the development of pro-social and civil attitudes. This research's added value is precisely the jointly evaluation of these variables.

Finally, another particularity of our study materialised in assessing the effect of Service Learning on teaching self-efficacy, an indicator of both the levels of learning among students [49] and the degree of satisfaction among teachers [50].

The link between self-efficacy and civic participation is shown to be important [41,51], as well as the skills-based training provided by Service Learning programmes [52]; but studies are significant as they correlate the improvement of the self-efficacy of students with the training and development of Service Learning programmes [53] or with the development and perception of an effective teaching personality [54], and our results are thus consistent with comparable studies.

Moreover, the data obtained from the research allows us to conclude that, of the analysed variables, the teaching self-efficacy variable and its correlation with Service Learning presents higher levels of correlation than in the case of volunteering. In addition, this shows that the students who display a greater socio-educational commitment (both in general and in its two dimensions) are also those who have a greater general teaching self-efficacy and self-efficacy with the use of materials.

Our research provides approaches to the current knowledge of the subject of study, but it also shows some limitations that we will try to minimise in future works. It would be convenient to continue deepening the subject with experimental studies that specifically relate to the learning methodologies aimed at promoting the development of civic and social competencies in higher education which do not include the limitations inherent to correlational and quasi-experimental studies.

Moreover, although we are of the view that the variables that we have addressed define the social commitment of future teachers, it would also be important to analyse other predictive variables, such as the family component or participation in social programmes in the stages of compulsory education. In this sense, it could also be interesting to expand the research with a sample that provided a greater heterogeneity with respect to the university degrees studied. This would facilitate a more complete view of pro-social attitudes on university campuses.

The popular image of the university in society is that of a centre of knowledge and research, as well as a professional space. The COVID-19 pandemic has forced an adaptation in which digital technologies have been reorientated towards hitherto unaddressed teaching and learning models [55]. However, the real crossroads is in structuring the right interrelationship between society and the university.

This study provides evidence and reasons for higher education institutions to continue to promote Service Learning programmes in order to minimise the distance between university centres and the new social realities from the strategy of University Social Responsibility [24], in what Oakes, Lipton, Anderson and Stillman [56] have called 'teaching to change the world' (p. 427). Training teachers in socio-educational commitment is a pillar of the sustainable university as teachers become diverse and inspiring agents for the sustainability and social justice awareness of their own students in their professional future.

In any case, it can be concluded that at the time of assessing Service Learning in student teachers, higher education institutions will have to face the challenge of incorporating 
it into their curricular programmes [33]. They would also have to develop curricular structures that promote civic and social competency. The university of the 21st century deals with the responsibility of assuming a social and educational role that fosters civic attitudes related to social justice and performance, in line with socio-educational, solidarity and ethical actions.

Supplementary Materials: The following are available online at https://www.mdpi.com/article/10 $.3390 /$ su132011445/s1, Table S1: Study 1 data collection.

Author Contributions: Conceptualization, J.T.A., E.S. and B.U.; methodology, E.S. and B.U.; validation and formal analysis, B.U. and E.S.; investigation, J.T.A. and E.S.; resources, J.T.A.; writingoriginal draft preparation, J.T.A., E.S. and B.U.; writing-review and editing, J.T.A., E.S. and B.U.; project administration, J.T.A. and E.S.; All authors have read and agreed to the published version of the manuscript.

Funding: This research received no external funding.

Institutional Review Board Statement: Not applicable.

Informed Consent Statement: Not applicable.

Data Availability Statement: The data presented in this study are available in Supplementary Materials, Table S1: Study data collection.

Conflicts of Interest: The authors declare no conflict of interest.

\section{References}

1. McIntosh, N.A.; Nenonene, R.L. In This Spirit: Helping Preservice Teachers Thrive during the Pandemic Through Adaptation and Change. J. Catholic Educ. 2020, 23, 162-174. [CrossRef]

2. Porlán, R. El cambio de la enseñanza y el aprendizaje en tiempos de pandemia. Revista de Educación Ambiental y Sostenibilidad 2020, 2, 1502. [CrossRef]

3. Williamson, B.; Eynon, R.; Potter, J. Pandemic politics, pedagogies and practices: Digital technologies and distance education during the coronavirus emergency. Learn. Media Technol. 2020, 45, 107-114. [CrossRef]

4. Bozkurt, A.; Jung, I.; Xiao, J.; Vladimirschi, V.; Schuwer, R.; Egorov, G.; Lambert, S.R.; Al-Freih, M.; Pete, J.; Olcot, D.; et al. A Global Outlook to the Interruption of Education Due to COVID-19 Pandemic: Navigating in a Time of Uncertainty and Crisis. Asian J. Distance Educ. 2020, 15, 1-126. Available online: https:/ / files.eric.ed.gov/fulltext/EJ1290039.pdf (accessed on 29 August 2021).

5. COVID-19 Educational Disruption and Response. Available online: https://en.unesco.org/news/covid-19-educationaldisruption-and-response (accessed on 29 August 2021).

6. Aramburuzabala, P.; Cerrillo, R.; Tello, I. Aprendizaje-servicio: Una propuesta metodológica para la introducción de la sostenibilidad curricular en la universidad. Profesorado 2015, 19, 78-95. Available online: http:/ /www.ugr.es/ \{\}recfpro/rev191ART5.pdf (accessed on 29 August 2021).

7. Rodríguez-Chueca, J.; Molina-García, A.; García-Aranda, C.; Pérez, J.; Rodríguez, E. Understanding sustainability and the circular economy through flipped classroom and challenge-based learning: An innovative experience in engineering education in Spain. Env. Educ. Res. 2020, 26, 238-252. [CrossRef]

8. Hébert, A.; Hauf, P. Student learning through service-learning: Effects on academic development, civic responsibility, interpersonal skills and practical skills. Act. Learn. Higher Educ. 2015, 16, 37-49. [CrossRef]

9. García, J.; Ruiz, M.; Del Pozo, A. Developing Civic Engagement in Distance Higher Education: A Case Study of Virtual Service-Learning (vSL) Programme in Spain. Open Praxis 2017, 9, 235-244. [CrossRef]

10. Novella-García, C.; Cloquell-Lozano, A. The ethical dimension of digital competence in teacher training. Educ. Inf. Technol. 2021, 26, 3529-3541. [CrossRef]

11. Aramburuzabala, P. Aprendizaje-Servicio: Una herramienta para educar desde y para la justicia social. RIEJS 2013, 2, 5-11. Available online: http:/ / www.rinace.net/riejs/numeros/vol2-num2/editorial.pdf (accessed on 29 August 2021).

12. Balddwin, S.C.; Buchanan, A.M.; Rudisill, M.E. What teacher candidates learned about diversity, social justice, and themselves from service-learning experiences. J. Teach. Educ. 2007, 58, 315-327. [CrossRef]

13. Gratch, A. Social Justice Advocacy in Graduate Teacher Education. J. Educ. Learn. 2018, 7, 1-11. [CrossRef]

14. Spitzman, E.; Balconi, A. Social Justice in Action: A Document Analysis of the Integration of Social Justice Principles into Teaching. J. Scholarship Teach. Learn. 2019, 19, 1-17. [CrossRef]

15. Amaro, A.; Martínez, N. Importancia de la educación inclusiva y justicia social en época de pandemia. Rev. Int. De Apoyo a La inclusión, Logopedia Sociedad Y Multiculturalidad 2020, 6, 135-144. [CrossRef] 
16. Potts, A.; Schlichting, K. Developing Professional Forums that Support Thoughtful Discussion, Reflection, and Social Action: One Faculty's Commitment to Social Justice and Culturally Responsive Practice. Int. J. Teach. Learn. Higher Educ. 2011, 23, 11-19. Available online: https:/ / files.eric.ed.gov/fulltext/EJ938574.pdf (accessed on 29 August 2021).

17. Mayor, D. Aprendizaje-Servicio como estrategia metodológica para impulsar procesos de educación expandida. Multidscip. J. Educ. Res. 2020, 10, 47-74. [CrossRef]

18. Uruñuela, P.M. La Metodología Del Aprendizaje-Servicio. Aprender Mejorando El Mundo; Narcea: Madrid, Spain, 2018.

19. Torrego, L.; Martínez, S.; Sonlleva, M. ¿Es posible la formación de personas éticas y comprometidas en la universidad? La asignatura de Educación para la paz y la igualdad en los Grados de Magisterio. Aula Abierta 2018, 47, 415-422. [CrossRef]

20. Bejarano, A.M. Educación inclusiva, criticidad y compromiso social. Innovación docente y Aprendizaje-Servicio en la formación inicial docente. REDU 2020, 18, 233-248. [CrossRef]

21. Boni, A.; Gasper, D. La Universidad como debiera ser. Propuestas desde el desarrollo humano para repensar la calidad de la Universidad. Sistema 2011, 220-221, 93-109. Available online: https://www.researchgate.net/publication/280245006_La_ Universidad_como_debiera_ser_Propuestas_desde_el_desarrollo_humano_para_repensar_la_calidad_de_la_Universidad (accessed on 29 August 2021).

22. Pantoja, A. Buenas Prácticas En La Tutoría Universitaria; Editorial Síntesis: Madrid, Spain, 2020.

23. Santos, M.A.; Sotelino, A.; y Lorenzo, M. El Aprendizaje-Servicio en la Educación Superior: Una vía de innovación y de compromiso social. Educación y Diversidad 2016, 10, 17-24. Available online: https:/ /www.researchgate.net/publication/3213 18720_El_aprendizaje-servicio_en_la_Educacion_Superior_Una_via_de_innovacion_y_de_compromiso_social (accessed on 29 August 2021).

24. Sirignano, F.M. El modelo europeo de Universidad y los retos pedagógicos en la sociedad globalizada. In Investigación En Docencia Universitaria: Diseñando El Futuro a Partir De La Innovación Educativa; Roig, R., Ed.; Octaedro: Barcelona, Spain, 2017 ; pp. 3-7.

25. Naval, C. Aproximación a la responsabilidad social universitaria: La respuesta de la universidad a la sociedad. Bordon 2012, 64, 103-115. Available online: https:/ / recyt.fecyt.es/index.php/BORDON/article/view/22053 (accessed on 29 August 2021).

26. Bringle, R.G.; Brown, L.A.; Hahn, T.W.; Studer, M. Pedagogies and civic programs to develop competencies for democratic culture and civic learning outcomes. Bordon 2019, 71, 27-43. [CrossRef]

27. European Council. Council recommendation of 22 May 2018, on key competences for lifelong learning. Off. J. Eur. Union 2018, 189, 1-13. Available online: https:/ / eur-lex.europa.eu/legal-content/EN/TXT/PDF/?uri=CELEX:32018H0604(01) (accessed on 2 September 2021).

28. Rodríguez-Izquierdo, R.M. Validación de una escala de medida del impacto del aprendizaje-servicio en el desarrollo de las competencias profesionales de los estudiantes en formación docente. Rev. Mex. Psicol. 2019, 36, 63-73. Available online: http:/ / comeppsi.com/images/rmp/rmp_036_01_063-073.pdf (accessed on 29 August 2021).

29. Rubio, L.; Escofety, A. (Eds.) Aprendizaje y Servicio: Claves Para su Desarrollo en la Universidad; Octaedro: Barcelona, Spain, 2018.

30. Montserrat, P.; Escofety, A.; Rubio, L. El desarrollo de la competencia investigadora a través de los proyectos de aprendizajeservicio. Codiseño y validación de una herramienta formativa para los futuros profesionales de la educación. Bordón 2019, 71, 79-95. [CrossRef]

31. Santos, M.A.; Mella, I. y Sotelino, A. Movilidad y TIC en aprendizaje-servicio: Perspectivas para una sociedad global y tecnológica. RIED. Rev. Iberoam. Educ. Distancia 2020, 23, 67-84. [CrossRef]

32. Sánchez, L.; Benítez, R.; Quesada, V.; García, M. Competencias emocionales en la formación inicial del profesorado. El aprendizaje y servicio como estrategia para su desarrollo. Bordón 2019, 71, 185-203. [CrossRef]

33. Aramburuzabala, P.; Mcllrath, L.; Opazo, H. Embedding Service Learning in European Higher Education; Routlede: London, UK, 2019. [CrossRef]

34. Bandura, A. Self-efficacy: Toward a unifying theory of behavioral change. Psychol. Rev. 1977, 84, 191-215. [CrossRef]

35. Flores, G.; Fowler, D.J.; Posthuma, R.A. Educational Leadership, Leader-Member Exchange and Teacher Self-Efficacy. J. Global Educ. Res. 2020, 4, 140-153. [CrossRef]

36. Rosal, I.; Bermejo, M.L. Autoeficacia en estudiantes universitarios: Diferencias entre el grado de maestro en educación primaria y los grados en ciencias. Int. J. Dev. Educ. Psychol. 2017, 1, 115-123. [CrossRef]

37. Chen, X. Pre-Service Teachers' Self-Efficacy of Interdisciplinary Team Teaching through the Use of Collaborative Concept Map. Int. J. Technol. Teach. Learn. 2020, 15, 76-94. Available online: https:/ / files.eric.ed.gov/fulltext/EJ1276247.pdf (accessed on 29 August 2021).

38. Hua, J.; Zhang, G.; Coco, C.; Zhao, T.; Hou, N. Proactive Personality and Cross-Cultural Adjustment: The Mediating Role of Adjustment Self-Efficacy. J. Int. Stud. 2020, 10, 817-835. [CrossRef]

39. Prieto, L. Autoeficacia Del Profesor Universitario. Eficacia Percibida Y Práctica Docente; Narcea: Madrid, Spain, 2007.

40. Torre, J.C. La Autoeficacia, La Autorregulación Y Los Enfoques De Aprendizaje En Estudiantes Universitarios; Servicio de publicaciones de la Universidad Pontificia Comillas: Madrid, Spain, 2007.

41. Ingellis, A.G.; Leone, L. Fomento de la autoeficacia, esperanza hacia el futuro y compromiso con la comunidad. Prism. Soc. 2016, 17, 438-463. Available online: https: / revistaprismasocial.es/article/view/1292 (accessed on 29 August 2021).

42. Redondo-Corcobado, P.; Fuentes, J.L. La investigación sobre el Aprendizaje Servicio en la producción científica española: Una revisión sistemática. RCDE 2020, 31, 69-82. [CrossRef] 
43. García, J.; Corrales, C. Las políticas supranacionales de educación superior ante la «tercera misión» de la Universidad: El caso del aprendizaje-servicio. Revista Española de Educación Comparada 2021, 37, 256-280. [CrossRef]

44. Burch, G.F.; Giambatista, R.; Batchelor, J.H.; Burch, J.J.; Hoover, J.D.; Heller, N.A. A Meta-Analysis of the Relationship between Experiential Learning and Learning Outcomes. Decis. Sci. J. Innov. Educ. 2019, 17, 239-273. [CrossRef]

45. Miyazaki, T.; Anderson, J.B.; Jones, S. The Influence of Service-Learning on the Civic Attitudes and Skills of Japanese Teacher Education Candidates. Int. J. Res. SL Teach. Educ. 2017, 5, 1-10. Available online: https://www.suss.edu.sg/docs/default-source/ default/44-the-influence-of-service-learning-on-the-civic-attitudes-and-skills-of-japanese-teacher-education-candidates.pdf (accessed on 29 August 2021).

46. Hervás, M.; Fernández, F.D.; Arco, J.L.; Miñaca, M.I. Efectos de un programa de Aprendizaje-Servicio en el alumnado universitario. Electron. J. Res. Educ. Psychol. 2017, 15, 126-146. [CrossRef]

47. Havlik, S.A.; Bialka, C.; Schneider, K. Theory to Practice: Integrating Service-Learning into a Pre-Practicum Introduction to School Counseling Course. J. Couns. Prep. Superv. 2016, 8, 3. [CrossRef]

48. Palpacuer-Lee, C.; Curtis, J. Into the Realm of the Politically Incorrect: Intercultural Encounters in a Service-Learning Program Int. J. Multicult. Educ. 2017, 19, 163-181. Available online: https://files.eric.ed.gov/fulltext/EJ1148052.pdf (accessed on 29 August 2021). [CrossRef]

49. Zimmerman, B.J. Self-regulatory cycles of learning. In Conceptions of Self-Directed Learning, Theoretical and Conceptual Considerations; Straka, G.A., Ed.; Waxman: Munster, Germany, 2000; pp. 221-234.

50. MEC. TALIS 2018 (II). La autoeficacia y la satisfacción del profesorado. Educainee 2019, 55. Available online: https: / / sede.educacion.gob.es/publiventa/boletin-de-educacion-educainee-n-55-talis-2018-ii-la-autoeficacia-y-satisfaccion-delprofesorado/educacion-estadisticas/23001 (accessed on 29 August 2021).

51. Santaolalla, E.; Asenjo, J.T.; Urosa, B.; Martín, O. Impacto de los proyectos de Aprendizaje Servicio en la autoeficacia docente de los maestros en formación. In Transformación Universitaria, Retos Y Oportunidades; Ediciones Universidad de Salamanca: Salamanca, Spain, 2021; pp. 361-368. [CrossRef]

52. Cooke, N.K.; Pursifull, A.K.; Jones, K.M.; Goodell, L.S. Layered Learning, Eustress, and Support: Impact of a Pre-Service-Learning Training on Students' Self-Efficacy in Teaching in the Community. J. Scholarship Teach. Learn. 2017, 17, 1-18. [CrossRef]

53. Bernadowski, C.; Perry, R.; Del Greco, R. Improving Preservice Teachers' Self-Efficacy through Service Learning: Lessons Learned. Int. J. Instr. 2013, 6, 67-86. Available online: https:/ / files.eric.ed.gov/fulltext/ED544043.pdf (accessed on 29 August 2021).

54. Chiva-Bartoll, O.; Gil-Gómez, J.; Zorrilla-Silvestre, L. Improving the effective personality of pre-service teachers through service-learning: A physical education approach. RIE 2019, 37, 327-343. [CrossRef]

55. European Commission. Digital Education Action Plan (2021-2027). Available online: https://ec.europa.eu/education/sites/ education/files / document-library-docs/deap-communication-sept2020_en.pdf (accessed on 2 September 2021).

56. Oakes, J.; Lipton, M.; Anderson, L.; Stillman, J. Teaching to Change the World; Routledge: New York, NY, USA, 2018. [CrossRef] 